\title{
Penerapan Self-Directed Learning (SDL) dalam Pembelajaran Fisika SMA Berbasis Daring Pada Pokok Bahasan Hukum Newton
}

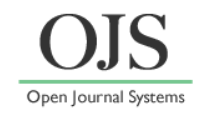

\author{
Silvia Ayu Permatasari ${ }^{*}$, Mita Anggaryani \\ Jurusan Fisika, Fakultas Matematika dan Ilmu Pengetahuan Alam, Universitas Negeri Surabaya \\ *Email: silvia.17030184096@mhs.unesa.ac.id
}

DOI: https://doi.org/10.33369/pendipa.5.3.403-411

\begin{abstract}
Currently, all Indonesian regions are experiencing a severe pandemic condition that affected all fields, including the education sector. The education system that is usually face-to-face has to turn online, which forces students with teaching staff to carry out the learning process from home. With online-based learning, teachers and students can take advantage of online learning-based platforms, like Google Classroom, to implement Self-Directed Learning (SDL), where there are adjustments to learning devices and material to be taught online and achieve the competencies to be trained. By using the preexperimental design method, the type of research used was one group pretest-posttest design. This article aims to apply Self-Directed Learning (SDL) in online-based high school physics learning on the subject of Newton's Law. The data analysis technique used is implementation of the learning process, normality test, paired t-test, and n-gain analysis. The application of Self-Directed Learning (SDL) is declared effective if the value on the final test (posttest) has a high value compared to the value of the initial test (pretest), as well as an increase in the results of the application of Self-Directed Learning (SDL) which is shown from the n-test. gain in the high category. In conclusion, the results of the application of SelfDirected Learning (SDL) can be done practically and are categorized as very good. The application of SDL is able to improve students' cognitive abilities in online-based physics learning for Newton's Law material.
\end{abstract}

Keywords: Self-Diected Learning (SDL); Physics Learning Based Online; Newton Law.

\begin{abstract}
ABSTRAK
Saat ini seluruh wilayah Indonesia sedang mengalami kondisi pandemi yang melanda segala bidang, termasuk bidang pendidikan. Sistem pendidikan yang biasanya tatap muka harus online, yang memaksa siswa dengan staf pengajar untuk melaksanakan proses pembelajaran dari rumah. Dengan pembelajaran berbasis online, guru dan siswa dapat memanfaatkan platform berbasis pembelajaran online, seperti Google Classroom, untuk menerapkan Self-Directed Learning (SDL), dimana terdapat penyesuaian bentuk penelitian memakai metode Pra-eksperimen, dengan desain penelitian one group pretest-posttest design. Artikel ini bertujuan untuk mengaplikasikan Self-Directed Learning (SDL) dalam pembelajaran fisika SMA berbasis online pada mata pelajaran Hukum Newton. Dalam melakukan analisis data menggunakan teknik analisis keterlaksanaan proses pembelajaran, uji normalitas, uji paired sample t-test, uji n-gain. Penerapan Self-Directed Learning (SDL) dinyatakan efektif jika nilai pada tes akhir (posttest) memiliki nilai yang tinggi dibandingkan dengan nilai tes awal (pretest), serta terjadinya peningkatan dari hasil penerapan Self-Directed Learning (SDL) yang ditunjukan dari uji n-gain dengan kategori tinggi. Sehingga dari penelitian ini dapat disimpulkan yaitu hasil penerapan Self-Directed Learning (SDL) dapat dilakukan secara praktis dan dikategorikan sangat baik. Penerapan SDL mampu meningkatkan kemampuan kognitif siwa dalam pembelajaran fisika berbasis online untuk materi Hukum Newton.
\end{abstract}

Kata kunci: Self-Directed Learning (SDL); Pembelajaran Fisika berbasis daring; Hukum Newton. 


\section{PENDAHULUAN}

Dunia dikejutkan oleh sebuah berita perihal suatu penyakit dengan sebutan Corona Virus Disease atau lebih dikenal dengan Covid-19. Peristiwa Covid-19 di Indonesia untuk pertamakali diumumkan pada tanggal 2 Maret 2020. Pemerintah Indonesia telah melakukan sebuah kebijakan yang bertujuan untuk mengurangi kasus penyebaran Covid-19 dengan melakukan pemberlakuan PSBB (Pembatasan Sosial Bersekala Besar) diberbagai daerah dengan tetap memberlakukan social distancing dan physical distancing.

Kebijakan yang dirilis guna mencegah penyebaran Corona Virus Disease memiliki dampak pada banyak aspek termasuk pendidikan di Indonesia (Herliandry dkk., 2020). Dengan menyebarnya kasus Covid-19 menurut surat edaran Keppres No.7 tahun 2020 menyatakan bahwa didunia terjadi peningkatan penyebaran dari Corona Virus Desasea 2019 (Covid-19). Organisasi WHO menyatakan pada 11 Maret 2020 bahwa Virus Corona atau Covid-19 menjadi pandemik. Dan saat ini Indonesia sedang mengalami kondisi pandemik yang cukup serius yang mengharuskan guru dan siswa untuk belajar dirumah seperti kebijakan yang telah dikeluarkan oleh Mendikbud dalam Surat Edaran Nomor 4 Tahun 2020 disampaikan mengenai prosedur pembelajaran dilakukan dari rumah dengan pembelajaran berbasis daring/online. Hal ini dapat memberikan sebuah pengalaman bagi siswa, tanpa dibebani tuntutan kecapaian kurikulum sebagai kenaikan kelas maupun kelulusan. Hal ini dilakukan sebagai pertimbangan utama sebagai kebijakan pendidikan yang menyangkut kesehatan bagi kepala sekolah, guru, siswa, dan warga sekolah. Covid-19 mengakibatkan pengujian secara mendesak pada pembelajaran secara online yang sebelumnya hampir tidak pernah dilaksanakan (Sun dkk., 2020). Tentunya di awal akan membingungkan bagi pendidik dan siswa karena sistem pendidikan yang berubah, dimana semula siswa belajar di sekolah yang menggunakan metode luring dan secara mendadak beralih pada kegiatatan pembelajaran yang dilakukan dari rumah. Lalu dipakai untuk pembelajaran dengan metode daring (Online) (Mahardini, 2020). Pendidikan secara daring diartikan menjadi pemindahan experience dan wawasan dengan memakai picture, video, audio, text communication, dan software (Basilaia \& Kvavadze, 2020) serta melalui bantuan sebuah koneksi internet (Zhu \& Liu, 2020). Pembelajaran daring memiliki penyajian yang berbasis web yang menjadi lebih interaktif serta tidak memiliki batasan dalam mengakses yang memungkinkan dapat dilakukan kegiatan pembelajaran dengan waktu yang lebih banyak.

Pembelajaran daring memiliki kelebihan yakni memiliki sarana e-moderatoring yang mana pendidik serta siswa dapat berinteraksi dengan mudah kapan saja atau dimana saja tanpa terbatas oleh jarak, lokasi, dan durasi hanya dengan memiliki akses jaringan internet. Siswa dapat mereview bahan pelajaran dimana saja, dapat mengakses internet apabila siswa memerlukan informasi terkait dengan materi yang dipelajari, serta terjadi perubahan peran siswa dari yang sebelumnya pasif menjadi aktif (Suhery, dkk. 2020). Pembelajaran Online dalam penggunaannya memiliki keuntungan yakni pembelajaran bersifat mandiri serta interaktif yang besar, dapat meningkatkan ingatan, mendapatkan pengalaman belajar yang banyak, melalui video, audio, teks, dan animasi untuk digunakan sebagai cara dalam menyampaikan pengetahuan atau informasi dengan memberikan sebuah kemudahan (Rosali (2020). Pembelajaran berbasis online atau daring tidak terlepas dari penggunaan internet serta pemanfaatan teknologi.

Penggunaan internet serta teknologi multimedia dapat dijadikan sebuah cara dalam merombak penyampaian pengetahuan serta menjadi alternatif pelaksanaan pembelajaran dalam sebuah kelas (Zhang dkk., (2004). Maka, internet dapat dimanfaatkan di bidang edukasi untuk mempermudah kegiatan pembelajaran dalam menjadi sumber referensi dan informasi pengetahuan yang diperlukan dalam masa pandemi saat ini. Dengan adanya internet para siswa dapat mengakses pengetahuan secara mudah, bebas, luas secara daring. Dengan ini pendidik dapat memanfaatkan platform pembelajaran dengan berbasis daring yang menjadi kebutuhan pembelajaran jarak jauah atau daring serta menghadapi masa pandemi dalam meningkatkan keterampilan siswa dan menghadapi tuntutan masa ini pada era revolusi industri 4.0. 
Prasarana ruang diskusi yang dapat digunakan dalam mendukung pembelajaran berbasis online secara gratis seperti Microsoft 365, Kelas Cerdas, Zenius, Quipper, Whatsapp, dan Google Classroom (Abidah dkk., 2020). Pada kondisi seperti ini guru dihadapi oleh tantangan besar agar proses pembelajaran tetap berlangsung serta dapat melatihkan keterampilan kepada peserta didik yang dapat dilakukan dengan menggunakan platform yang tepat karena pendidikan sangatlah penting. Dari berbagai platform salah satu diantaranya yang dapat dipergunakan sebagai pembelajaran berbasis online atau daring melalui aplikasi Google Classroom.

Kegiatan pembelajaran secara online dapat diimplementasikan dengan menggunakan Google Classroom yang memungkinkan pendidik dengan siswa dapat melaksanakan kegiatan pembelajaran tidak tatap muka didalam kelas dengan diberikan sebuah materi dalam bentuk slide power point, buku elektronik, video pembelajaran, pekerjan individu maupun berkelompok (Rosali, 2020).

Pemanfaatan dari aplikasi Google Classroom memangnya dapat mempermudah pendidik dalam mengelolah kegiatan pembelajaran serta penyampaian informasi dengan akurat dan cepat bagi para siswa (Hardiyana, 2015). Google classroom sebagai sarana yang membantu dalam kesulitan dan menjadi jalan keluar penugasan dalam bentuk kertas (paperless) (Gunawan \& Sunarman, 2018). Sehingga dapat dikatakan Google Classroom bersifat ramah lingkungan karena siswa tidak perlu memakai kertas untuk menyerahkan tugasnya. Google classroom dapat dijadikan sebagai pilihan media yang dapat dimanfaatkan untuk pembelajaran online atu daring bagi para guru selama melakukan pembelajaran daring dan dapat menjadi sarana siswa dalam mengumpulkan tugas-tugas (Rahmanto \& Bunyamin, 2020). Sehingga platform Google Classroom dapat dimanfaatkan sebagai pertimbangan media untuk digunakan pada pembelajaran berbasis daring pada saat menghadapi masa pandemi untuk mengembangkan kemampuan Self-Directed Learning (SDL) siswa pada materi Hukum Newton.
Penggunaan dari e-learning secara tepat dapat menciptakan sebuah lingkungan belajar yang terpusat kepada siswa atau student-centred learning, hal ini dikarenakan penggungaan sistem pembelajaran elekronik siswa dituntut untuk belajar secara mandiri serta dapat mengkonstruksi pengetahuannya sendiri (Vega N D \& Arifin, 2016). Sistem pembelajaran yang berorientasi pada siswa memiliki paradigma bahwa siswa hanya menerima materi dari guru saja. Hal ini perlu diubah agar siswa dapat lebih meningkatkan mandiri untuk belajar fisika dan tidak lagi pasif serta dapat bertanggung jawab dalam setiap kegiatan pembelajaran. SelfDirected Learning (SDL) mengarah pada keaktifan siswa saat proses pembelajaran dan dideskripsikan sebagai agenda terencana dan peninjauan proses afektif dan kognitif yang mengikuti keberhasilan pengelolaan tugas secara akademik (Palacios \& Gascon, 2010). SelfDirected Learning (SDL) merupakan cara agar siswa sebagai pengendali proses pembelajaran dapat terlibat dalam mengidentifikasi, mengorganisir dan menentukan apa yang mereka pelajari. Hal tersebut jelas berbeda dengan belajar sendiri karena guru tetap berperan sebagai pengendali pembelajaran bertanggungjawab mengorganisir dan menyediakan materi pembelajaran. Sedangkan dalam SDL siswa dapat berkelompok atau belajar secara mandiri tanpa kehadiran guru (Kirkman, 2007). Siswa harus aktif dalam memperoleh pengetahuannya secara mandiri seperti dalam mata pelajaran fisika. Pada hakikatnya fisika merupakan sebuah a body of knowlenge (produk belajar), a way of investigasting (proses), dan a way of thinking (sikap) (Sutrisno, 2006). Fisika adalah sebuah sains yang meninjau alam semesta berupa ilmu fenomena alam dari aspek materi serta energinya.

Pada masa pandemi saat ini pembelajaran daring yang menggunakan Google Classroom dapat memberikan pengalaman belajar baru yang berpusat kepada siswa. Penelitian ini bertujuan untuk mendeskripsikan peluang penerapan SelfDirected Learning (SDL) dalam pembelajaran fisika siswa SMA berbasis daring pada pokok bahasan Hukum Newton. Peneliti meyakini bahwa platform Google Classroom dapat digunakan untuk merancang pembelajaran Fisika yang menerapkan SDL. 
Tabel 3. Instrumen Angket Self-Directed Learning (SDL)

\begin{tabular}{llc}
\hline No. & \multicolumn{1}{c}{ Pernyataan } & $\begin{array}{c}\text { Jenis } \\
\text { pernyataan }\end{array}$ \\
\hline $\mathbf{1}$ & $\begin{array}{l}\text { Saya belajar materi yang } \\
\text { telah dibagikan oleh guru } \\
\text { untuk pertemuan }\end{array}$ & \\
& $\begin{array}{l}\text { selanjutnya } \\
\text { Saya belajar atas kemauan } \\
\text { saya sendiri }\end{array}$ & Positif \\
& & \\
\end{tabular}

3

Saya akan belajar ketika sudah diperintah oleh orang tua/guru

4

Ketika mengalami kesulitan memahami materi saya memiliki inisiatif untuk belajar bersama dengan teman sebaya

5 Saya berusaha mencari berbagai sumber untuk tugas saya

6 Saya aktif dalam menjawab pertanyaan atau tugas yang diberikan guru

7 Sebelum belajar saya membuat jadwal kegiatan belajar dengan rapi agar tidak merasa bosan

8 Saya belajar sesuai dengan jadwal yang telah saya buat

9 Saya belajar materi pelajaran untuk pertemuan berikutnya dengan mencatatnya

10 Saya belum bisa memanfaatkan waktu belajar dengan baik

11 Saya belajar materi Hukum Newton agar menguasai materi pelajaran tersebut.

12 Saya berusaha mengerjakan soal Hukum Newton agar mengetahui seberapa kemampuan yang saya miliki.

13 Saya tidak berusaha menguasai mata pelajaran Hukum Newton karena tidak sesuai dengan keinginan saya

14 Saya berkonsultasi dengan guru mata pelajaran agar menguasai mata pelajaran tersebut

15 Saya aktif belajar materi Negatif Hukum Newton hanya pada saat akan ulangan harian

16 Saya menggumpulkan tugastugas yang diberikan guru dengan tepat waktu

17 Ketika selesai pembelajaran saya mengulangi materi yang saya dapat pada saat poses pembelajaran agar lebih paham

18 Saya mencari referensi
Negatif

Positif

Positif

Positif

Positif

Positif

Positif

Negatif

Positif

Positif

Negatif

Positif

Positif

Positif

Positif 
materi di sumber lain ketika saya kesulitan memahami materi di salah satu sumber belajar

19 Saya yakin pada kemampuan sendiri bahwa saya akan mendapatkan nilai yang bagus

20 Ketika tes/ulangan saya mengerjakan dengan kemampuan sendiri

21 Saya yakin pada jawaban saya sendiri meskipun jawaban saya berbeda dengan yang lain

22 Saya lebih yakin mengambil pendapat orang lain dari pada pendapat saya sendiri

23 Saya merasa termotivasi dengan teman yang mempunyai prestasi belajar yang tinggi

24 Saya menggerjakan tugas dengan sungguh-sungguh dan teliti

25 Saya merasa senang belajar meskipun nilai saya jelek

26 Apabila ada materi pelajaran yang belum saya pahami saya mencari sumber belajar yang lain

$27 \quad$ Apabila ada tugas yang sulit saya menyudahi mengerjakan tugas tersebut dan mengharapkan hasil pekerjaan teman saya

28 Setiap mengerjakan tugas, saya tidak menyontek hasil pekerjaan teman

29 Saya sering melihat pekerjaan orang lain kemudian menulis ulang pekerjaan tersebut

30 Ketika guru memberikan kesempatan untuk bertanya maka kesempatan itu saya biarkan saja meskipun ada materi pelajaran yang belum saya pahami

31 Setiap ada permasalahan dalam memahami materi pelajaran, saya bertanya kepada guru,teman, atau orang lain

\section{Saya tidak membuat Positif contekan pada saat akan mengerjakan tes/ulangan}

Positif

Positif

Positif

Negatif

Positif

Positif

Positif

Positif

Negatif

\begin{tabular}{ll}
\multicolumn{2}{c}{ Learning (SDL) Siswa } \\
\hline \multirow{3}{*}{ Indikator } & \multicolumn{2}{l}{ Jenis Pernyataan } \\
\cline { 2 - 3 } & Negatif Positif
\end{tabular}

untuk mengisi angket terkait Self-Directed Learning (SDL). Berikut ini adalah hasil analisis angket Self-Directed Learning (SDL) pada siswa.

Tabel 4. Persentase Data Angket Self-Directed

\begin{tabular}{lll} 
Kesa daran untuk belajar \\
\cline { 2 - 3 } mandiri
\end{tabular} 72,$37 \% \quad 82,89 \%$

Memiliki perencanaan

dalam belajar

Memiliki tujuan belajar $\quad 93,42 \% \quad 70,18 \%$

Kedisiplinan dalam

belajar

$71,05 \% \quad 84,65 \%$

Percaya diri

$73,68 \% \quad 82,89 \%$

Kerja keras $\quad 82,89 \% \quad 80,26 \%$

\begin{tabular}{lcc} 
Sifat original & $81,58 \%$ & $78,29 \%$ \\
\hline Rata -rata & $77,82 \%$ & $78,54 \%$ \\
\hline Kriteria & Baik & Baik \\
\hline
\end{tabular}

Pada Tabel 4 memperlihatkan respon siswa pada pernyataan positif sebesar $78,54 \%$ dan pernyataan negatif sebesar $77,82 \%$ yang memiliki kategori baik (telah melewati kriteria) berdasarkan 19 responden (siswa) dari 33 siswa. Jumlah responden yang sedikit diakibatkan oleh Positif jumlah item pernyataan yang terlalu banyak, sehingga membuat siswa kehilangan minat untuk mengisi angket. Disarankan dalam waktu pengisian angket tidak boleh lebih dari 10 menit (Jogianto, 2005).

Selanjutnya penelitian ini juga didapatkan Negatif nilai pretest dan posttest, guna memahami data yang diperoleh pada penelitian terdistribusi normal ataukah tidak sehingga dapat dilakukan sebuah uji normalitas.

Positif

Tabel 5. Uji Normalitas

\begin{tabular}{cccc}
\hline Kelas & $X_{\text {tabel }}^{2}$ & \multicolumn{2}{c}{$X_{\text {hitung }}^{2}$} \\
\cline { 3 - 4 } & & Pretest & Posttest \\
\hline X IPA 3 & 11,07 & 0,144 & 0,068 \\
\hline
\end{tabular}


Berdasarkan pada Tabel 5 dapat diketahui pada hasil uji normalitas yakni nilai dari $X_{\text {hitung }}^{2}<X_{\text {tabel }}^{2}$ maka dapat diartikan bahwa $\mathrm{H}_{0}$ diterima. Sehingga dapat disimpulkan dari kelas $X$ IPA 3 yang dijadikan subjek penelitian dikatakan terdistribusi normal.

Berdasarkan tes yang diberikan kepada siswa untuk mengetahui penerapan Self-Directed Learning (SDL) memiliki perbedaan sebelum diberikan treatment dan sesudah diberikan treatment ditunjukkan oleh grafik perolehan ratarata pretest dan posttest berikut ini.

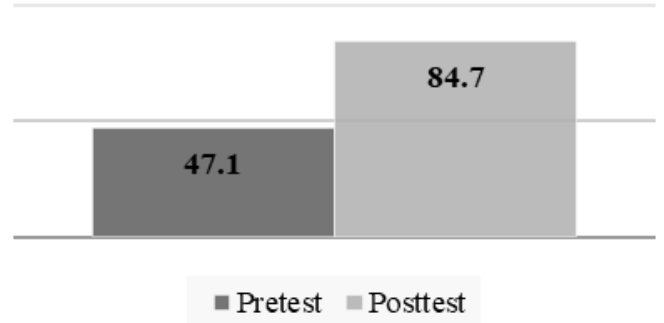

Gambar 2. Grafik Rata-rata Perolehan Nilai Pretest dan Posttest

Pada grafik Gambar 2 dapat diketahui adanya perbedaan antara nilai pada pretest serta nilai posttest. Sehingga dari grafik tersebut dapat dikatakan bahwa penerapan Self-Directed Learning (SDL) efektif pada pembelajaran fisika berbasis daring dengan menggunakan Google Classroom.

Tabel 6. Rata-Rata Kemampuan Kognitif Siswa

\begin{tabular}{lcc}
\hline \multicolumn{1}{c}{ Ranah Kognitif } & \multicolumn{2}{c}{ Persentase } \\
& \multicolumn{2}{c}{ Kem ampuan Kognitif } \\
\cline { 2 - 3 } & Pretest & Posttest \\
\hline Mengingat (C1) & $58,6 \%$ & $91,9 \%$ \\
Memahami (C2) & $54,5 \%$ & $84.8 \%$ \\
Meng aplikasi (C3) & $43,2 \%$ & $84,1 \%$ \\
Menganalisis (C4) & $42,4 \%$ & $83,1 \%$ \\
\hline Rata-rata & $49,7 \%$ & $86,0 \%$ \\
\hline
\end{tabular}

Pada Tabel 6 dapat diketahui bahwa kemampuan kognitif siswa yakni dalam C1, C2, C3, dan C4 memperlihatkan perbedaan, dimana persentase posttestt lebih tinggi dibandingkan dengan persentase pretest. Sehingga dapat disimpulkan bahwa telah tercapainya ketuntasan kemamuan siswa mencapai ranah kognitif setelah diberikan perlakuan yang mungkin pada awalnya belum tercapai (sebelum diberikan perlakuan).

Uji t-berpasangan dilakukan agar dapat mengetahui adanya sebuah perbedaan antara Self-Directed Learning (SDL) sebelum dilaksanakan sebuah treatment dan setelah dilakukan treatment dengan memperhatikan dari perolehan pretest dan nilai posttest berikut ini:

Tabel 7. Uji Paired Sample T Test

\begin{tabular}{clll}
\hline Kelas & $\boldsymbol{t}_{\text {tabel }}$ & $\boldsymbol{t}_{\text {hitung }}$ & Hipotesis \\
\hline X IPA 3 & 1,69 & 11,03 & $H_{0}$ ditolak \\
\hline
\end{tabular}

Dapat dilihat dari perolehan Uji Paired Sample T Test pada Tabel 7 bahwa nilai dari $t_{\text {hitung }}>t_{\text {tabel }}$ pada kelas X IPA 3 dengan nilai $\alpha=0,05$, sehingga dapat disimpulkan hipotestis $\mathrm{H}_{0}$ ditolak. Dengan demikian ditemukan selisih nilai pretest dan posttest pada saat sebelum diterapkan Self-Directed Learning (SDL) dan setelah diterapkan Self-Directed Learning (SDL). Pada tahapan selanjutnya dilakukan analisis pada perolehan tes awal dan tes akhir guna mengetahui pengembangan Self-Directed Learning (SDL) dengan menggunakan analisis $n$ gain.

Perhitungan dengan menggunakan uji $n$-gain dari perolehan tes awal (pretest) dan tes akhir (posttest) guna melihat adanya pengembangan keterampilan. Hasil perhitungan dengan uji $n$ gain dapat dilihat berikut ini.

Tabel 8. Uji n-gain

\begin{tabular}{ccc}
\hline Kelas & $\langle\boldsymbol{g}\rangle$ & Kategori \\
\hline X IPA 3 & 0,71 & Tinggi \\
\hline
\end{tabular}

Berdasarkan Tabel 8 dapat dilihat bahwa nilai dari Uji n-gain pada kelas X IPA 3 mempunyai kategori tinggi, dimana hal tersebut dapat ditarik kesimpulan bahwa penerapan SelfDirected Learning (SDL) efektif pada pembelajaran fisika berbasis daring pada pokok bahasan Hukum Newton. 


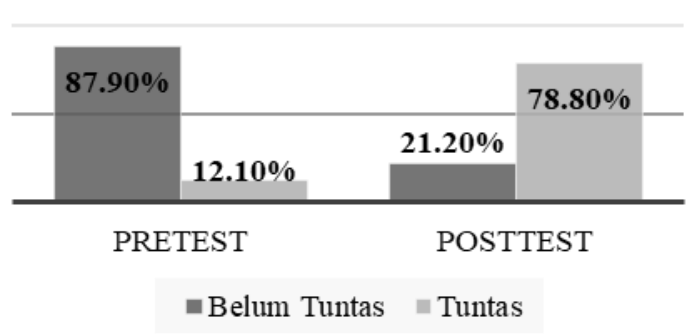

Gambar 3. Grafik Ketuntasan Belajar Klasikal

Pada Gambar 3 dapat dilihat bahwa ranah kognitif pada siswa kelas X IPA 3 dengan jumlah 33 siswa bahwa pada saat pretest terdapat 29 siswa dinyatakan belum tuntas belajar dengan perolehan nilai $\leq 75$ dan 4 siswa dinyatakan tuntas dengan memperoleh nilai sebesar $\geq 75$. Sedangkan pada hasil pelaksanaan posttest didapatkan bahwa terdapat 7 siwa dinyatakan belum tuntas pembelajaran dengan perolehan nilai $\leq 75$ dan 26 sisiwa 4 siswa dinyatakan tuntas dengan memperoleh nilai sebesar $\geq 75$.

\section{KESIMPULAN}

Dari hasil penelitian yang telah dilakukan, dapat disimpulakan bahwa penerapan SelfDirected Learning (SDL) efektif dalam pembelajaran fisika siswa SMA berbasis daring pada pokok bahasan Hukum Newton. Hal tersebut ditunjukkan oleh nilai n-gain dengan kategori tinggi pada kelas X IPA 3 yang berarti bahwa terdapat peningkatan Self-Directed Learning (SDL) dalam pembelajaran berbasis daring serta ketercapaian kemampuan ranah kognitif siswa. Oleh karena itu, pembelajaran fisika berbasis daring dapat dijadikan sebuah alternatif untuk menerapkan sebuah keterampilan Self-Directed Learning (SDL) pada siswa dalam kondisi yang memiliki sedikit interaksi langsung antara siswa dan guru. Namun, penelitian ini memiliki keterbatasan dalam hal waktu penerapan untuk bisa digunakan menganalisis perubahan sikap siswa dalam belajar secara akurat. Penelitian lebih lanjut tentang SDL di waktu yang akan datang perlu memperhatikan aspek perubahan sikap yang merupakan produk dari hasil belajar secara mandiri.

\section{DAFTAR PUSTAKA}

Abidah, A., Hidaayatullaah, H. N., Simamora, R. M., Fehabutar, D., \& Mutakinati, L.
(2020). The Impact of Covid-19 to Indonesian Education and Its Relation to the Philosophy of "Merdeka Belajar. Studies in Philosophy of Science and Education, 1(1), 38-49.

Aziza, Lilik Fadlilatin. (2012). Hubungan antara Self Efficacy dengan Self Directed Learning pada Mahasiswa Program Studi Psikologi Fakultas Dakwah IAIN Sunan Ampel Surabya. Skripsi. Surabaya: Institute Agama Islam Negeri Sunan Ampel.

Basilaia, G., \& Kvavadze, D. (2020). Transition to Online Education in Schools during a SARS-CoV-2 Coronavirus (COVID-19) Pandemic in Georgia. Pedagogical Research, 5(4).

Gunawan, Sunarman. (2018). Pengembangan Kelas Virtual Dengan Google Classroom dalam Keterampilan Pemecahan Masalah (Problem Solving) Topik Vektor pada Siswa SMK untuk Mendukung Pembelajaran. Prosiding Seminar Nasional Etnomatnesia, 340-348.

Hardiyana, A. (2015). Implementasi Google Classroom sebagai Alternatif dalam Meningkatkan Mutu Pembelajaran di Sekolah. Karya Tulis Ilmiah, Cirebon: SMA Negeri 1 Losari.

Herliandry, L. D., Nurhasanah, N., Suban, M. E., \& Kuswanto, H. (2020). Pembelajaran Pada Masa Pandemi Covid-19. JTPJurnal Teknologi Pendidikan, 22(1), 65-70.

Ipmawati, Sufi (2012). Keefektifan Metode Pembelajaran Resitasi Dalam Meningkatkan Kemandirian Belajar Dan Hasil Belajar Ekonomi Kelas X Sma Muhammadiyah 1 Muntilan Tahun Pelajaran 2011/2012. Skripsi. Universitas Negeri Yogyakarta.

Jogiyanto. (2005). Metodologi Penelitian Bisnis: Salah Kaprah dan Pengalaman. Yogyakarta: BPFE

Keputusan Presiden. (2020). Nomor 7 Tahun 2020 Tentang Gugus Tugas Percepatan Penanganan Corona Virus Disease 2019 (COVID-19).

Kirkman, S., Coughlin, K., \& Kromrey, J. (2007). Correlates of satisfaction and success in self-directed learning: relationships with school experience, 
course format, and internet use. International Journal of Self-Directed Learning, 4(1), 39-52.

Mahadini. (2020). Analisis Situasi Penggunaan Google Classroom Pada Pembelajaran Daring Fisika. JPF Jurnal Pendidikan Fisika, 8(2).

Menteri Pendidikan. (2020). Surat Edaran Nomor 4 Tahun 2020 Tentang Pelaksanaan Pendidikan dalam Masa Darurat CoronaVirus (COVID-19)

Palacios, A. Gascon, G. (2010). Self-Regulated Learning Environments. Attitude as Antecedent variable, ICERI2010 Proceedings, 1678-1686.

Rahmanto, M. A., \& Bunyamin. (2020). Efektivitas Media Pembelajaran Daring Melalui Google Classroom. Jurnal Pendidikan Islam, 11(2), 119-135.

Rosali, E. S. (2020). Aktifitas Pembelajaran Daring Pada Masa Pandemik Covid-19 di Jurusan Pendidikan Geografi Universitas Siliwangi Tasikmalaya. Geography Science Education Journal (GEOSEE), 1.
Suhery, Putra, T. J., Jasmalida. (2020). Sosialisasi Penggunaan Aplikasi Zoom Meeting dan Google Classroom Pada Guru di SDN 17 Mata Air Padang Selatan. Jurnal Inovasi Penelitian, 1(3).

Sun, L., Tang, Y., Zuo, W. (2020). Coronavirus pushes education online. Nature Materials, 9, 687.

Sutrisno. (2006). Fisika dan Pembelajaranya. Bandung: Universitas Pendidikan Indonesia

Vega, N. D., dan Arifin. (2016). Penerapan Self Directed E-Learning Pada Keterampilan Menyimak the Implementation of Self Directed E-Learning of Listening Skill. Jurnal Masyarakat Telematika dan Informasi, 7(2), 107-118.

Zhang, D., Zhao, J. L., Zhou, L., \& Nunamaker, J. F. (2004). Can e-learning replace classroom learning? Communications of the ACM, 47(5).

Zhu, X., \& Liu, J. (2020). Education in and After Covid-19: Immediate Responses and LongTerm Visions. 